\title{
The Role of Entrepreneurship and Foreign Direct Investments on the Relation between Digital Divide and Economic Growth: A Structural Equation Model
}

\author{
Mustafa Emre Civelek*, Murat Çemberci**, Nagehan Uca *** \\ * İstanbul Ticaret Üniversitesi, **İstanbul Ticaret Üniversitesi, *** İstanbul Ticaret \\ Üniversitesi \\ E-mail: ecivelek@ticaret.edu.tr,mcemberci@ticaret.edu.tr
}

Copyright (C) 2016 Mustafa Emre Civelek, Murat Çemberci, Nagehan Uca. This is an open access article distributed under the Eurasian Academy of Sciences License, which permits unrestricted use, distribution, and reproduction in any medium, provided the original work is properly cited.

\begin{abstract}
The digital divide is the non-distribution of technologic infrastructure use equiponderant within the society and an inequality in proportion to the tendency to technological use within the social categories. There is a significant correlation between the dissemination of information to the society and technology. Developments in the information and communication technologies affect the economic growth of countries. The possibility of accessing to the information strengthens the individual and this positively affects the entrepreneurship capacity of individual in the new fit system which the knowledge becomes the most important factor of production. This study tests the model which shows the relation between digital divide, economic growth, and entrepreneurship, patent granted and foreign direct investment. Internet penetration (IP) was used as the measurement criterion of digital divide. The hypotheses, suggested in the study, were tested through the method of structural equation model, and it was found that all of the hypotheses within the relation range, offered in the study model, were statistically significant.
\end{abstract}

Keywords: Digital Divide, Internet Penetration, Gross Domestic Product, Foreign Direct Investment, Entrepreneurship

\section{The Role of Entrepreneurship and Foreign Direct Investments on the Relation between Digital Divide and Economic Growth: A Structural Equation Model}

\section{ÖZET}

Dijital bölünme, teknolojik altyapının kullanımının toplum içerisinde eşit ağırlıklı ola-rak yayılmaması ve toplum kesimleri arasında teknoloji kullanımına yatkınlık oranındaki eşitsizliktir. Bilginin topluma yayılması ile teknoloji arasında önemli bir ilişki vardır. Bilgi ve 
iletişim teknolojilerindeki gelişmeler, ülkelerin ekonomik büyümesini etkilemektedir. Bilginin en önemli üretim faktörü haline geldiği yeni ekososyal sistemde bilgiye erişim olanağı bireyi güçlendirmekte ve bu da bireyin girişimcilik kapasitesini olumlu etkilemektedir. $\mathrm{Bu}$ araştırma, dijital bölünme, ekonomik büyüme, girişimcilik, tescil edilmiş patent (patent granted) ve doğrudan yabancı yatırımın arasındaki ilişkiyi ortaya koyan modeli test etmektedir. Dijital bölünmenin ölçüm kriteri olarak internet penetrasyonu (IP) kullanılmıştır. Araştırmada ileri sürülen hipotezler yapısal eşitlik modeli yöntemi ile test edilmiş, araştırma modelinde önerilen ilişki silsilesi içerisinde yer alan hipotezlerin tamamı istatistiksel olarak anlamlı (statistically significant) bulunmuştur.

Anahtar Kelimeler: Dijital Bölünme, İnternet Penetrasyonu, Gayri Safi Yurtiçi Hasıla, Doğrudan Yabancı Yatırım, Girişimcilik

\section{Introduction}

There is a very close relation between dissemination of information to the society and technology. The scientific enlightenment and technologic developments have triggered each other during the history. Following the scientific enlightenment eras, the great technological developments emerged and the technological developments have triggered the scientific enlightenment by facilitating the accession of human to the knowledge. The best example for this is the invention of printing press. Upon invention of printing press, the information was disseminated toward the base and the information asymmetry between the social categories was minimized. In this context, nowadays, emerging of internet is a very important development comparable with the invention of printing press. Internet has facilitated accessing to the information ever before and huge amounts of information has become easily usable by the people.

However, the reached technological level is not valid for all communities and the people living in such communities today. Recently, there is an inequality between the individuals and companies worldwide in the sense of use of technology, accessing to the communication channels and information (Park, Choi, \& Hong, 2015). Nowadays, there are serious differences between the individuals who use the internet and who may not use it because of not having an internet connection regarding the accessing to information. As internet facilitates the individual's accessing to the information, it also increases his/her power. The individual is able to broadcast at home to the world upon spreading of Web 2.0 technologies. In particular, increasing in the use of social media also enhances the activities of individual and consumer. However, there are many people who don't have any internet access worldwide. Those people could not experience the digital development that those who had the internet access experienced. This causes the serious disintegration between the social categories so that this fact is called as digital divide. Inequality between the social categories regarding accessing to the technological possibilities doesn't lead to the sociologic problems only, but has the serious economic results for the country. Considering the digital divide figures, it is observed that there is a relation between the development level of a country and digital divide (Norris, 2001). In another study, Billon et al. found that there was a positive and significant relationship between GDP which was one of the important economic indicators and digital divide in a study, executed on the different country groups. (Billon, Lopez, \& Marco, 2010). 
Considering the detailed literature related to the digital divide, Quibria et al. studied the relation between digital divide and income status, education, infrastructure for the Asian countries. (Quibria, Ahmed, Tschang, \& Reyes-Macasaquit, 2002). Beilock and Dimitrova showed the relation between internet use, income status, infrastructure, personal computer and phone usage. (Beilock \& Dimitrova, 2003). In one of the papers published by the World Bank, Rodrigez and Wilson created a technology development index using five variables, taking the personal computer, mobile phone, Internet Host, Fax and TV as the outputs and tried to develop a methodology in order to measure the digital divide. (Rodríguez \& Wilson III, 2000). In another work published in 2006, Guillen and Suarez considered the digital divide regarding telecommunication and showed the relation between internet accessing cost and phone usage and GDP so as covering 118 countries. (Guillen \& Suarez, 2006). Similarly, there are also works showing the relation between telecommunication, infrastructure, economic factors, literacy rate, personal computer usage rate, competition and digital divide (Oyelaran-Oyeyinka \& Lal, 2005).

Since the digital divide is directly related to the technologic infrastructure deficiencies of the country and to the human resource quality in that country, it has also impact on the foreign direct investments which that country attracts (E.Prieger, 2013). Furthermore, empowerment of the individuals, having the internet access during the digital development process, has a positive impact on the entrepreneurship ability of them (Lin, et al., 2015). Conversion of information into a production factor within the new eco-social system, called new economy, also increases the entrepreneurship capacity of individuals whom their information access capacity is increased through internet (Park, Choi, \& Hong, 2015).

Since the entrepreneur, himself/herself, is an individual production factor, coming of information and entrepreneur together causes the important developments in the country's economy. When increasing in the foreign direct capital, which the country attracts, is added to this, decreasing in the digital divide rate in a country has a positive impact regarding the growth (Barfield, Heiduk, \& Welfens, 2003).

\section{Conceptual Framework}

\subsection{Digital Divide (IP)}

The digital divide may be described as the non-distribution of technologic infrastructure use equiponderant within the society and an inequality in proportion to the tendency to technological use within the social categories. Non-distribution of technologic infrastructure equally is a problem that is generally found in the developing countries, and the latter, namely, inequality in the tendency toward proportion of the use of technology among the individuals of society is a fact which is found in the developed countries depending on the proportion of young and entrepreneur population (Cruz-Jesus, Oliveira, \& Bacao, 2012).

It is described in the report of OECD, dated 2001 as follows. "The digital divide refers to the gap between individuals, households, businesses and geographic areas at different socio-economic levels with regard to their opportunities to access information and communication technologies and to their use for a wide variety of activities" (OECD, 2001).

The third type of digital divide is the gap occurring depending on the proportion of technological use between the countries. Measurement of digital divide between the countries is easier than the first two types. Digital divide is a problem which may causes the living standard and income imbalance 
between the social categories. The ratio of digital divide in a country is measured in accordance with three criteria. Those are the numbers of telephone subscription, PC, and internet user. In this research, the number of internet user was used. It is assumed that the increasing in internet penetration has the positive impact on the country's growth (Barzilai-Nahon, 2006). In this research, the internet penetration (IP) was used as the measurement criterion of digital divide.

The digital divide within the society may also damage to the economic structure of the country. The lacks of qualified work force, production potential and the most important, unfair distribution of income are observed in the countries where the digital divide significantly occurs (Zhang, 2013). As some part of society continues to develop fast and has the significant part of total income, the social class at the bottom of digital divide continues to experience the unfair distribution of income, unemployment and similar problems (Barfield, Heiduk, \& Welfens, 2003).

\subsection{Global Entrepreneurship Index (GEI)}

Enterprise is the most important driver of economic growth. Emergences of enterprises in an economy need entrepreneur which create innovation, productivity growth, and new jobs. To development of entrepreneurial success in a country, there should be a promotive environment. Entrepreneurship rises in the context of particular conditions such as qualified labor force, convenient cultural structure and society. The environment consists of attitudes, resources and infrastructure are known as the entrepreneurship ecosystem.

The Global Entrepreneurship Index is an annual index that measures the health of the entrepreneurship ecosystems in each of 120 countries. It then ranks the performance of these against each other. This provides a picture of how each country performs in both the domestic and international context. The GEDI methodology collects data on the entrepreneurial attitudes, abilities and aspirations of the local population and then weights these against the prevailing social and economic 'infrastructure' - this includes aspects such as broadband connectivity and the transport links to external markets. This process creates 14 'pillars' which GEDI uses to measure the health of the regional ecosystem (The Global Entrepreneurship and Development Institute, 2015).

\subsection{Patent Grant (PG)}

A patent grant is an intellectual property right granted by governments to an inventor "to exclude others from making, using, offering for sale, or selling the invention throughout the related country or importing the invention into the related country" for a limited time in exchange for public disclosure of the invention when the patent is granted (Patent Grant Data Products, 2015). In this research data obtained from The World Bank is used for patent grant dimension.

\subsection{Foreign Direct Investment (FDI)}

Foreign direct investment refers to direct investment equity flows in the reporting economy. It is the sum of equity capital, reinvestment of earnings, and other capital. Direct investment is a category of cross-border investment associated with a resident in one economy having control or a significant degree of influence on the management of an enterprise that is resident in another economy. Ownership of 10 percent or more of the ordinary shares of voting stock is the criterion for determining the existence of a direct investment relationship. Data are in current U.S. dollars (Foreigh direct Investment Net Inflows, 2015). FDI is directly affected from the attractiveness of economic conditions 
of a country. In this research, effects of divide on economy are asserted. Regarding foreign direct investment, The World Bank database has been used.

\subsection{Economic Growth (GDP)}

The economic growth represents the increasing of production capacity, production and thus, the national income in a country. The figures of Gross National Product (GNP), which is one of the important indicators for the countries, are one of the digital criteria giving information about the common economic situation. In this work, GNP is used as the dependent variable. Gross Domestic Product data is taken from The World Bank database.

\section{Research Method}

In this research, the structural equation modeling method, which is a statistical technique that is prevalently used recently, was used. One of the reason why this method is prevalent is to consider the measurement errors in the measured variables. Another reason is to recommend the new arrangements related to the relations in the model, if necessary. The measurement errrors are eliminated by this way. The structural equation modeling (SEM) takes the covariance matrix as basis different than the regression model. The correlation matrix is taken as basis in the regression models. As the regression analyses should be performed individually for each relation in the regression anaylsis, all relations that are determined between the variables can be understood through one analysis in the analyses with SEM (Dursun \& Kocagöz, 2010).

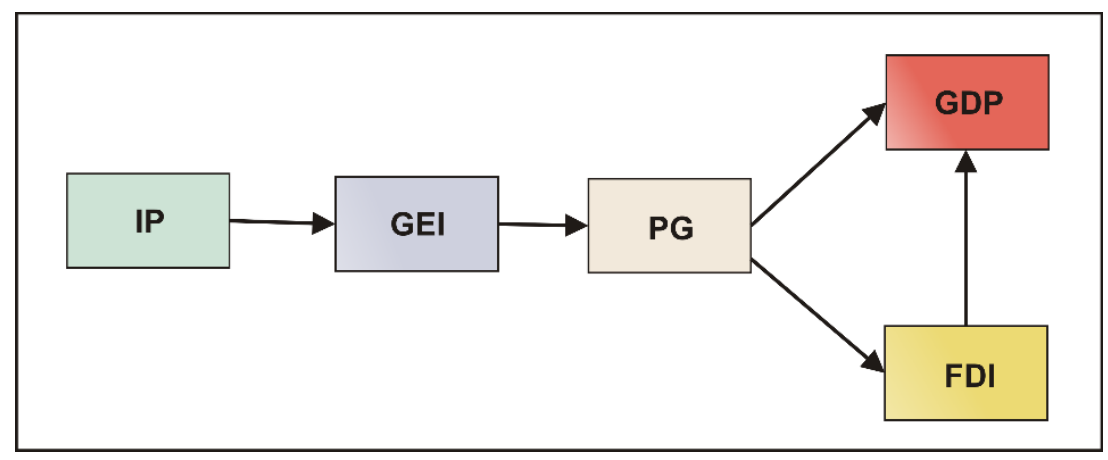

Figure 1. Research Model

Figure 1 shows the research model. Table 1 includes the research hypotheses.

Table 1. Summary of the Hypothesis

\begin{tabular}{|l|}
\hline$H_{1}:$ GEI is positively influenced by IP. \\
\hline $\mathrm{H}_{2}$ : PG is positively influenced by GEI. \\
\hline $\mathrm{H}_{3}$ : GDP is positively influenced by PG. \\
\hline $\mathrm{H}_{4}:$ FDI is positively influenced by PG. \\
\hline $\mathrm{H} 5:$ GDP is positively influenced by FDI. \\
\hline
\end{tabular}

\section{Analysis Results}

The fit of obtained data to the model is evaluated according to the several fit indices. CMIN/DF, CFI, TLI, GFI, RMSA scales are the recognized scales in the literature (Byrne, 2010). 
CMIN is the Likelihood Ratio Chi-Square Test. This test shows the consistency between envisaged model and obtained model. Being the CMIN/DF ratio smaller than 3 and insignificancy of chi-square value indicate that the general fit of model is within the acceptable limits (Meydan \& Şeşen, Yapısal Eşitlik Modellemesi AMOS Uygulamaları, 2011). As shown in the Table 2, it is found that CMIN/DF value is 2,120 and that the chi-square value is insignificant in the research model analysis results. Thus, it may be suggested that the general fit of research model is within the acceptable limits.

CFI fit scale is an incremental fit statistics which compares the independent model that there is not any relation between the variables with the tested and saturated models. It takes the value between 0 and 1 , and the value beyond 0,90 indicates the good fit (Schermelleh-Engel, Moosbrugger, \& Müller, 2003). As shown in the Table $2, \mathrm{CFI}$ value was found as 0,980 in the research model analysis results. Therefore, it may be said that there is not a good fit in the research model.

AGFI fit scale is calculated considering the degree of freedom. As the sample volume increases, AGFI value also increases. AGFI value varies between 0 and 1 . The values beyond 0,90 indicate that the fit is good (Bayram, Yapısal Eşitlik Modellmesine Giriş: AMOS Uygulamaları, 2013). As shown in the Table 2, AGFI value was found 0,860 in the research model analysis results. Since the value is very close to 0,90 and the research sample is limited with the number of country where the data can be obtained, it may be said that the value is within the acceptable limits.

GFI fit scale is an index showing the variance and covariance degree that is indicated by the model. As being in the AGFI fit scale, as the sample volume increases, the GFI value also increases in the GFI fit scale. This may prevent to obtain the correct result. GFI value varies between 0 and 1 . The values between 0,90 and 0,95 are considered as the indicator of acceptable model. This means that the covariance is calculated between the observed variables (Bayram, 2013). As shown in the Table 2, GFI value was found 0,953 in the research model analysis results. This value indicates that the model is acceptable.

RMSA fit scale is a fit scale which compares the average differences of each expected degree of freedom in the main mass. It is assumed that this scale is adversely influenced by the sample magnitude. 0,05 or lower value of RMSA fit scale indicates the good fit, and the values between 0,05 and 0,08 indicate the acceptable fit (Bayram, Yapısal Eşitlik Modellmesine Giriş: AMOS Uygulamaları, 2013). As shown in the Table 2, RMSA value was found 0,117 in the research model analysis results. However, since the research sample is limited with the number of country where the data can be obtained and when it is evaluated with other fit indices, it may be assumed that this value is within the acceptable limits.

Table 2. Model Fit Indices

\begin{tabular}{|c|c|c|}
\hline Fit Indices & Goodness of Fit Value & Model Values \\
\hline CMIN/DF & CMIN/DF $<3$ & 2,120 \\
\hline CFI & $0,9<\mathrm{CFI}<1$ & 0,980 \\
\hline AGFI & $0,9<\mathrm{AGFI}<1$ & 0,860 \\
\hline GFI & $0,9<\mathrm{GFI}<1$ & 0,953 \\
\hline RMSEA & $0<\mathrm{RMSEA}<0,05$ & 0,117 \\
\hline
\end{tabular}

The structural equation analysis was performed in AMOS data processing program in order to test the hypothesis. The Standard $\beta, C . R$. and $P$ values of hypothesis and the acceptance and rejection results are given in the Table 3 . 
Table 3. Path Analysis Results

\begin{tabular}{|c|c|c|c|c|}
\hline Hypothesis & Standard $\boldsymbol{\beta}$ & C.R. & $\mathbf{P}$ & Accept/Reject \\
\hline $\mathrm{H} 1$ & 0,816 & 12,794 & 0,00 & Accepted \\
\hline $\mathrm{H} 2$ & 0,250 & 2,336 & 0,019 & Accepted \\
\hline $\mathrm{H} 3$ & 0,536 & 11,004 & 0,00 & Accepted \\
\hline $\mathrm{H} 4$ & 0,517 & 5,462 & 0,00 & Accepted \\
\hline $\mathrm{H} 5$ & 0,528 & 10,843 & 0,00 & Accepted \\
\hline
\end{tabular}

Indication of Path analysis results on the diagram is as shown in the Table 4.

Table 4. Path Diagram

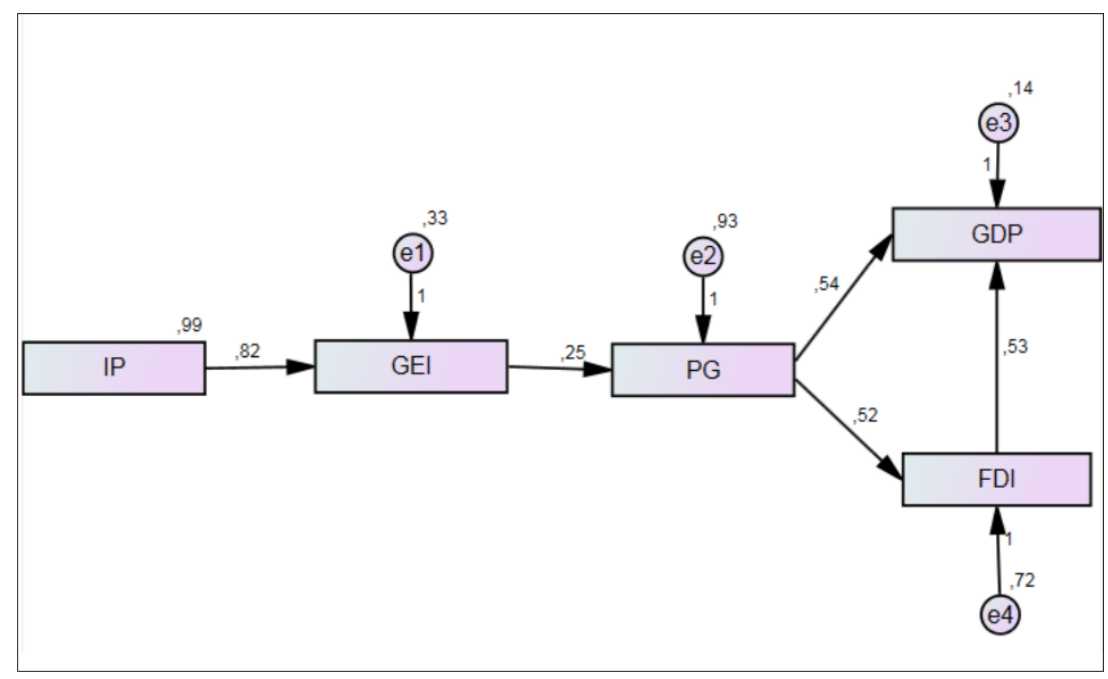

\section{Conclusion}

Since the internet is the main source of information in the today's information age, the individuals having internet access are ahead from others regarding the information access. Since the information access possibility by the individual strengthens the individual in the new eco-social system which the information is the most important production factor, this also positively affects the entrepreneurship capacity of individual. However, it is found that unless the entrepreneurship activities in the countries are legally protected under the patent registration, the entrepreneurship activities don't result in a new product. Likewise, the researches show that only two of hundred product development works are recognized in the market and turned into a new product. This supports the hypothesis which the productivity of patent registration process is one of the factors that will attract the foreign direct investment to the country. Therefore, it is suggested that there is a relation between the number of patent grant and foreign direct investment attracted to the country in the research model.

It is found that all of the hypotheses within the relation range that is suggested in the research model are statistically significant. The theoretical contribution of this research is to present a model which will form a basis for the researchers who will execute the research on this subject in the future. Since accessing to sufficient data only for 83 countries creates the limitation of this research and in the event that the sufficient data is obtained in the future researches, the model may be repeated on more countries. Furthermore, the model may be developed by adding different dimensions to the model. 
The managerial implication of the research is to encourage the internet literacy increasing projects to be implemented by the governments and the investments to the internet infrastructure upon illuminating the influences of digital divide on the country's economy.

\section{References}

- Barfield, C. E., Heiduk, G., \& Welfens, P. (2003). Internet, Economic Growth and Globalization. Heidelberg: Springer.

- Barzilai-Nahon, K. (2006). Gaps and bits: Conceptualizing measurements for digital divide/s. The Informa-tion Society, 5(22), 269-278.

- Bayram, N. (2013). Yapısal Eşitlik Modellmesine Giriş: AMOS Uygulamaları. BURSA: Ezgi Kitaevi.

- Beilock, R., \& Dimitrova, D. V. (2003). An exploratory model of inter-country Internet diffusion. Telecommunications Policy, s. 237-252.

- Billon, M., Lopez, F., \& Marco, R. (2010). Differences in digitalization levels: a multivariate analysis studying the global digital divide. Rev World Econ, s. 39-73.

- Byrne, B. M. (2010). Structural Equation Modeling with AMOS. New York: Routledge Taylor \& Francis Group.

- Cruz-Jesus, F., Oliveira, T., \& Bacao, F. (2012). Digital divide across the European Union. Information \& Management, 49(6), 278-291.

- Çelik, H. E., \& Yılmaz, V. (2013). Lısrel 9.1 ile Yapısal Eşitlik Modellemesi. Ankara: Anı Yayıncilık.

- Dursun, Y., \& Kocagöz, E. (2010). Yapısal Eşitlik Modellemesi ve Regresyon: Karşılaştırmalı Bir Analiz. Erciyes Üniversitesi, İBF Dergisi(35), 1-17.

- E.Prieger, J. (2013). The broadbanddigitaldivideandtheeconomicbenefitsof. Telecommunications Policy, 37(6-7), 483-502.

- Foreigh direct Investment Net Inflows. (2015). 09 21, 2015 tarihinde The World Bank: http://data.worldbank.org adresinden alınd 1

- Guillen, M. F., \& Suarez, S. L. (2006, December). Explaining the Global Digital Divide: Economic, Political and Sociological Drivers of Cross-National Internet Use. Social Forces.

- Lin, C. A., Atkin, D., Cappotto, C., Davis, C., Dean, J., Eisenbaum, J., et al. (2015). Ethnicity, digital divides and uses of the Internet for health information. Computers in Human Behavior, 51(A), 216-223.

- Meydan, C. H., \& Şeşen, H. (2011). Yapısal Eşitlik Modellemesi AMOS Uygulamaları. ANKARA: Detay Yayıncilik.

- Norris, P. (2001). Digital Divide: Civic Engagement, Information Poverty and the Internet Worlwide. Chambridge: Chambridge University Press. 
- OECD. (2001). Understanding the Digital Divide. Paris: OECD.

- Oyelaran-Oyeyinka, B., \& Lal, K. (2005). Internet diffusion in sub-Saharan Africa: A crosscountry. Telecommunications Policy, s. 507-527.

- Park, S. R., Choi, D., \& Hong, P. (2015). Club convergence and factors of digital divide across countries. Technological Forecasting \& Social Change, 1(96), 92-100.

- Patent Grant Data Products. (2015). 09 22, 2015 tarihinde United States Patent and Trade Office: http://www.uspto.gov adresinden alınd1

- Quibria, M. G., Ahmed, S. N., Tschang, T., \& Reyes-Macasaquit, M.-L. (2002). Digital Divide: Determinants and Policies with Special Reference to Asia. Manila-Philippines: Asian Development Bank.

- Rodríguez, F., \& Wilson III, E. J. (2000). Are poor countries losing the information revolution? Washington, DC: World bank.

- Schermelleh-Engel, K., Moosbrugger, H., \& Müller, H. (2003). Evaluating the Fit of Structural Equation Models: Tests of Significance and Descriptive Goodness-of-Fit Measures. Methods of Psychological Research Online, 8(2), 23-74.

- The Global Entrepreneurship and Development Institute. (2015). 09 22, 2015 tarihinde Global Entrepreneurship Index: http://www.thegedi.org adresinden alındı

- Zhang, X. (2013). Income disparityanddigitaldivide:TheInternet. Telecommunications Policy, 37(6-7), 515-529. 